\title{
Breaking The Mirror Of The Spectacle: Mass Murder/Suicide As The Ecstasy of Simulated Experience
}

\author{
Oliver Simpson, Lancaster University, United Kingdom
}

\begin{abstract}
The article develops a sociological understanding of the lone mass shooter and the ways in which his affectual constellation is produced within and mirror the social space. It begins by outlining the contemporary political context of terrorism. The article then explores the affectual constellation of an isolated mass murderer, by asking the question 'what is a loser?' The article then links the emergence of the radical loser to modernity through an exploration of the genealogy of nihilism. Then, taking the mass murderer Elliot Rodger as a paradigmatic case it explores the ways in which his affectual constellation can be understood as produced within the capitalist social formation. Finally, it argues that mass murder can be understood as the ecstasy of simulated experience, its violent counter transference, constituting a zone of indistinction between the spectacle and the real, killing and being killed.
\end{abstract}

\section{Keywords}

sociology, mass murder/suicide, radical loser, nihilism, spectacle, spite, simulated experience

\section{Introduction}

To begin it must be stated that the act of mass murder/suicide in and of itself is a kind of "empty signifier" in the sense meant by Laclau (2005: 69-76). The act is a constitutive shell, it does not have a pre-determined ideological content. However, that is not to say that a specific instance of mass murder/suicide is not ideologically motivated. Rather, mass murder/suicide can be thought of as an imperative, a form of action that is animated by a range of ideologies that vary across historical and social contexts. We have seen this form of act adopted by on the one hand white nationalists, Islamic fundamentalists, Christian fundamentalists and on the other hand mass murderers and school shooters who are not connected to a wider terrorist network. Despite the mass media consistently making a distinction between the terrorist acts of the networked fundamentalist and the acts of mass murder perpetrated by am "isolated, confused and angry young man" there are insufficient grounds in actuality to make a distinction between the acts and the tactics of the act at the micro level. Firstly, as I have already stated the act of mass murder/suicide does not have a pre-determined ideological content, secondly, as argued by Diken and Laustsen (2004:91) terror in the 21 st century is "post-political" that is to say,

Whereas the classical terror targeted political adversaries and aimed at a realization of a political program, the new terror is blind and diffuse. It operates stochastically and seldom demands something explicit from an identifiable adversary... Terror hits randomly: Anybody and everybody can be a potential target.

The new terrorist's choice of target is based upon the maximisation of death and destruction, hence the Manchester bomber and the Las Vegas shooters choice to target concerts and not specific individuals or political adversaries. Whereas once the terrorism in the modern, disciplinary society was perpetrated by an identifiable other who lived in the margins without "touching" the society (Diken and Laustsen, 2004:90). The new post-modern terrorism is the result of the objective conditions created by a singular hegemonic super power and the more this power consolidates on one network the more vulnerable this network is to attack (Baudrillard, 2003:405). New terror is internal to globalisation which gives rise to a new 
post-modern fear that anyone could be a terrorist and terrorism can hit at any time in any place making everyone a potential target (Diken and Laustsen, 2004:91). For example, the white nationalist perpetrator of the Christchurch Mosque shootings was described by the manager of the gym he worked at for several years "as normal as one person as to the next" who "never showed any extremes of extremist views or any crazy behaviour" (Regan and Sidhu 2019). Thirdly, both fundamentalist terrorism and the terrorism of the lone gunman combine real death with the real time images of the event, be that via mass media outlets in the case of the September 11th attack on the twin towers or filming and live streaming the attacks on the two Mosques' in Christchurch. Indeed, the Christchurch shooters use of social media made the event viral and virtual, his video and manifesto were downloaded and shared across a range of websites, turning social networks into network/spectacles for the global distribution of terror in real time. As the journalist Wigham (2019) described the attack,

the Christchurch shooting was carefully crafted for the internet age with its use of live streaming, the shouting out of popular meme slogans and the upload of his rambling manifesto replete with inside jokes geared to those steeped in underground internet subculture.

Additionally, many mass murderers not associated with a particular extremist network (which is not to say their views are not extremist) make use of YouTube and mass media outlets as a way in which they can advertise themselves, their act and the "Logic or philosophy" that motivated them (see Berardi, 2015:25-28). Thus, in opposition to the media construction of this individual as a lone gunman I have stated that formally, on the microlevel, they cannot be distinguished from those connected to terrorist networks. From this perspective mass murderers or lone gunmen are terrorists. Significantly, the symbolic and suicidal dimensions of the new terrorism signify a nihilist refusal to accept the world as it is, the denial of any and all political authority and the attempt to destroy the socio symbolic order (see Diken, 2008:28). The act is a radical nihilist gesture, the devaluation of the world in the name of valuations that cannot find a place in this world (Nietzsche, 1967:318). The act is thus not a neutral container, the meanings that fill it go beyond politics and ideology, aiming at the destruction of the self and the social. It is worth pointing out that the combination of selfdestruction and the destruction of the other mirrors Guattari's (2008:169) concept of the Fascist war machine, which in its German and Italian forms is invested with a fantastic, collective "death instinct" with Hitler and the Nazis fighting for death, right up to and including the death of Germany; the German masses agreed to follow along and meet their own destruction". Indeed, as remarked by Enzensberger (2005) the Nazi project from its inception was a suicidal one. Much like the Nazi party was a condensation of molecular Fascism, which is constituted by desires within the social space, we can argue that despite the fact many mass shooters are isolated individuals, it is not hard to see how these subjectivity's become entangled and crystallise into various contemporary fascistic assemblages such as religious fanatics, white nationalists or even the involuntary celibates who have adopted the mass murderer Elliot Rodger as a patron saint of the movement. That being said, mass murder/suicide such as school shootings often remain at the level of the individual and it is not unreasonable to claim many resists being integrated by any ideology or wider terrorist networks: seeing their struggle as a personal struggle. However, I want to draw a minimal distinction between the fanatic terrorist networks and the lone shooter as firstly, this actor remains surprisingly under-researched in social theory. Secondly, I will argue that the isolated mass murderer and their increasing prevalence in contemporary society can be read as symptomatic of the neoliberal turn in late capitalism and the eclipse of the social by spectacles and simulations. 
The article begins by asking the question "what is a loser?" in contemporary social life. It explores the neoliberal ideological construction of winners and losers. It then draws a distinction between the loser and the radical loser and explores the affectual constellation of the radical loser. This constellation includes the affects of depression, spite, and resentment as well as the desire for recognition. Spite is the affect of most importance as following Diken (2008:27) spite is "a willingness to harm oneself in order to harm other's; Thus, it encapsulates the logic of the constitutive shell that combines aggression with auto aggression, suicide with mass murder. The aim of this section is not to distil the absolute essence of mass murder/suicides. Rather, it aims to develop an ideal typical framework for its interpretation. Secondly, I will link the emergence of the radical loser to modernity through re-visiting the genealogy of nihilism as it provides a conceptual apparatus for thinking about the ways in which mass murder/suicide reflect and are produced within the social space. Thirdly, the article develops an account of the ways in which the affectual constellation of the radical loser is produced within the capitalist social formation. It does so with the paradigmatic example of Elliot Rodger whose world view and mass murder/suicide encapsulate the double economies of spiteful rage and a marketized view of sexual relations. A world view that is not only held by resentful online subcultures, but also reflected in popular culture.

Specifically, the work of the best-selling author Houellebecq whose fictional account of marketized sexual relations has a diagnostic value for our present investigation (see Diken, 2008:91). Finally, the article deals with the blurring or collapse of fiction and reality into integral violence, or the ecstasy of violence in which the separation of the body from experience, or simulated experience is countered by the "spectacular" mass murderer James Egan Holms (the joker). Arguing mass murder/suicide can be interpreted as the violent counter transference, or reversal of our experience as simulation.

\section{The loser and the radical loser}

What is a loser? The question invites a range of childish, banal, common-sense and pejorative answers from the bloated, self-satisfied and self-proclaimed winners of neoliberal capitalism. One rarely stops to ponder the question 'Am I a loser?'. As I will argue such self- reflexivity is a key entry point for understanding the lone mass murderer and their increasing significance and prevalence in contemporary social life. My contention is that what constitutes a loser undergoes a significant transformation in modernity, reaching its peak in neoliberal capitalist social formations. As a preliminary definition of a loser, following Nietzsche (1996:10-11), losers emerge from a confrontation of apposing systems of values, namely noble and slave moralities. The archetypal loser in Nietzsche's (1996) "On the Genealogy of Morals" is the priestly aristocracy, who originally emerged as the losers of the confrontation with knightly aristocrats, this situation was of course later reversed during what Nietzsche (1996:13) called the slave revolt in morality. However, the basic argument from this perspective is that the loser is the defender of a defeated system of values, the loser thus emerges from a confrontation between two groups with opposing values. Taking this definition as our point of departure, let us look at what the loser is in contemporary social life.

According to Sloterdijk (2010:40), "Modernity has invented the loser. This figure, which one meets halfway between yesterday's exploited and today's and tomorrow's superfluous, is the misunderstood product of the power games of democracies". Today the loser is a taken for granted, banal and permanent occupant in contemporary social life. The triumph of neoliberal economics, its emphasis on ruthless competition in conjunction with the citizens desire and striving for the scarce and " specific forms of recognition manifested in prestige, wealth, 
sexual advantage, and intellectual superiority" means in liberal democracies there will always be a large reservoir of losers (Sloterdijk, 2010:39,40). In the neoliberal society of individuals and free market competition, or "the society without society" (See Rossi, 2018:3) winning and losing becomes the dominant form of ideological and economic differentiation supplanting that of class conflict. As I will argue throughout the article, this ideological form of differentiation that places the emphasis on the individual provides a social context from which, the lone mass murderer or radical loser emerges. Thus, in contrast to Sloterdijk, it is not the loser that is the misunderstood product of modernity, but the radical loser, the subterranean other of contemporary social life that must be distinguished from the loser.

The loser in the neoliberal society takes many forms and responds to their circumstances in a variety of ways, there are those who are resigned and accept their fate, those who compose themselves and re-enter the competition and victims who demand compensation and reparation for their loss (Enzensberger, 2005). However, the radical loser responds by isolating themselves, planning and anticipating their hour of revenge (Enzensberger, 2005). What the loser who resigns themselves to their fate and the radical loser have in common is ressentiment, understood as a state of being in which powerful emotions such as anger, hate or envy cannot find an outlet and are thus turned inwards (Scheler, 1994:31). Such powerful emotions cannot find an outlet as according to Nietzsche (1996:15), the man of ressentiment is marked by weakness and an inability to act. Consequently, their memory replaces action, the resentful loser can only respond to their memories and imagine revenge. Take for example, Dostoyevsky's (1992: 19) underground man...

There, in its loathsome, stinking underground, our offended, beaten-down, and derided mouse at once immerses itself in cold, venomous, and, above all, everlasting spite. For forty years on end...it will recall everything, go over everything

The underground man describes himself as a spiteful man that "in reality could never become spiteful" (Dostoyevsky, 1992:14). Here in lies a crucial difference between the loser and the radical loser. The radical loser is not content with simply imagining revenge, their spite must be actualised, their pain must be shared with those who are seen as having a lack of pain (Sloterdijk, 2010: 56). The formation of this desire involves the radical loser taking an active role in the formation of their subjectivity as a loser. For the loser to become a radical loser they must adopt the judgement of those who consider themselves winners, saying to themselves "I am a loser and nothing but a loser" (Enzensberger, 2005). A contemporary example of this can be found in the adoption of a social Darwinian philosophy by Eric Harris, who wrote of his admiration of natural selection in his diary and on the day of the massacre wore a T-shirt with 'natural selection' printed on it (Berardi, 2015:37). The adoption of a pro natural selection philosophy is significant for Berardi as it reflects the killer's social education in the neoliberal age in which the strong have the right to win and dominate the weak.

The young man knew very well that he was not going to be a winner in the social game. Instead, he decides that he will be a winner for a moment: I'll kill and I'll win: then I'll die. The murderous action is conceived as revenge for the humiliation that he has suffered in the daily game of competition (Berardi. 2015:37)

The radical loser thus mirrors and adopts the rules of the social, their act is a nihilistic extension and intensification and one may say logical consequence of widely accepted hierarchies based on competition and the so called "survival and triumph of the fittest". 
Indeed, following Berardi 2015:38), the psychology of Eric Harris and Dylan Klebold could be synthetically described "as a suicidal form of the Neoliberal will to win". From this perspective that which constitutes a significant aspect of contemporary social life establishes and destroys the social. Spite is significant in this context: it is produced within the social space as a continual threat of disintegration and disorder (Diken, 2008:28). Spite is an affect without society, it does not just threaten the other, it extends beyond the individual blurring the line between the perpetrator and the victim. One of the ways spite has been articulated is as "running amok". According to Berardi (2015) running amok is an expression that comes from the Malay language.

In the original Malaysian context, a man who has previously shown no signs of violent anger acquires a weapon and, in a sudden frenzy, kills or injures anyone in the vicinity. Running amok is a way of re-establishing one's reputation as a man to be feared and respected but is also a way of escaping the world when life has become intolerable, and generally culminates in suicide. It's a culture-bound syndrome, whose manifestations are shaped by the cultural context and expectations. (Berardi, 2015:40).

Running amok thus combines a depressive paralysis with Thymotic impulses, which according to Sloterdijk (2010:11) is the part of the soul the ancients believed was responsible for rage, pride and the desire for respect and recognition. The violent breaking out of a depressive paralysis resulting from identifying as a loser is seen as the only means of attaining a feeling of power, it confirms ones existence in the moment of destroying the self and the other. It is spite that enables the radical loser to attain a feeling of power, winning for one moment before their own life ends.

Significantly however, spite is not just a means of attaining a feeling of power and breaking out of depressive paralysis. The harm of oneself, the renunciation of enjoyment and the immersion in pain and illusion brings with it a form of enjoyment. Indeed, according to Diken (2009:99) "Enjoyment and the renunciation of it are not opposing but complementary flows. That is, the 'radical loser' seeks equality in destruction of others together with himself'. The radical loser can only imagine a worsening of the evil conditions under which they suffer by extending their pain to the other. Thus, the radical losers demand for justice "emerges as the demand for the curtailment of the others enjoyment "since it is not possible to impose equal jouissance, what one can impose is only the equally shared prohibition" (Diken, 2009:99). It is through this equal prohibition the radical loser is able to turn renunciation into enjoyment. It can therefore be argued that spite is an extension to the other of one's own asceticism, understood as self-denial and the infliction of pain upon oneself (see Nietzsche 1996:11). Thus, in the climactic moment of actualised spite or "When running amok, the borders between one's body and the surrounding universe are blurred, and so is the limit between killing and being killed" (Berardi 2015:40). To understand this extension of the ascetic ideal to the other, it is worth discussing Diken's theorisation of the genealogy of nihilism.

\section{Radical and passive nihilism.}

Where is God gone? ... I mean to tell you! We have killed him, - you and I! We are all his murderers! (Nietzsche, 1960: 167) 
For Nietzsche (1967:9), the meaning of the death of god is that the highest values devaluate themselves. That is to say, belief in god, the "reality principle" the meta-physical reality that gave our world meaning collapses into the actual (see Baudrillard, 2005:18). The result is the emergence of two distinct, existential, subjective dispositions, the radical nihilist and the passive nihilist (Diken, 2008:22-27). The radical nihilist responds to the death of God with despair, the systematic undermining of belief in the monotheistic God and the otherworldly values he represents, pushes him to cling all the more desperately to his faith in these things. However, due to the world consistently undermining this faith, the radical nihilist is forced to accept the "absolute untenability of existence when it comes to the highest values one recognises" (Nietzsche, 1967: 3). The radical nihilist is left with absolute values that cannot find a place in this world and due to their desperate attachment to these values "they judge of the world as it is that it ought not to be" (Nietzsche, 1967: 318). With radical nihilism the link between man and God, this world and the next is severed. Existence in this world is no longer seen as the pre-condition to the next (Diken, 2008:27). That is to say, the radical nihilist's reduction of the world to nothingness by judgement is followed by a reduction of the world to nothing by hand (Nietzsche, 1967:18). This world's destruction becomes the precondition to the next. Unlike the subjects included in a Christian collective, who according to Sloterdijk, (2010:35) were pacified because they were able to invest and defer their rage in God, who functioned as a kind of large-scale rage bank. The radical nihilist becomes a direct instrument of God, bringing about this world's destruction themselves. Thus, with radical nihilism, the ascetic ideal once meant to pacify the explosive materials of ressentiment becomes an active "will" invested in this world (Diken, 2008:27). The destruction of themselves and the world is the means by which the radical nihilist can touch the real, realise what cannot be realised, that absolute ideal that cannot be found in this world.

In contrast to the radical nihilist, the passive nihilist responds to the death of god by accepting the end of those old religious values, concluding they live in a world without values (Diken, 2008:23). The passive nihilist accepts the impossibility of different forms of evaluation and thus the impossibility of placing a distance between the actual reality and the virtual, a domain that extends beyond the actual which enables differing and active forms of evaluation. Indeed, the passive nihilist is caught in a paradox whereby they cannot endure this world while they simultaneously cannot deny it (Nietzsche, 1967). Consequently, the passive nihilists existence is reactive, whereas the ascetic in the case of the radical nihilist is an active will invested in the production of pain: the passive nihilist avoids pain by denying their own will (Diken, 2008:23). The passive nihilists nothingness of the will separates happiness from action, reducing life to modest pleasures. This is Nietzsche's last man who has abandoned those places that are too hard to live in, who make themselves and the earth small "They have their little pleasures for the day, and their little pleasures for the night, but they have a regard for health. "We have discovered happiness,"- - say the last men, and blink thereby" (Nietzsche, 2016:26).

So, there we have it, the two losers of modernity, the loser who chooses to live in a world of passivity and modest pleasures and the radical loser who cannot accept their highest values do not have a place in this world and thus will nothingness rather than not willing. Crucially in this context although these nihilisms are juxtaposed to one another they operate within the same social space (Diken, 2008:3). Their relationship is one of a non-dialectical, disjunctive synthesis in which the injunction for moderation is paired with the desire for extremity (see Diken, 2008:3). It is this nihilistic deadlock that is characteristic of our social space, suggesting that the running amuck of the radical loser is produced and paired with the society of spectacular, simulated pleasure. Indeed, I stated in the beginning of the article, new terror 
is a radical nihilist gesture, the act is beyond politics and ideology, it is the paradoxical moment in which the unrealisable ideal is touched in the moment of destruction. This ideal does not have to be that of god, although terrorism in the name of god is still a persistent phenomenon in late capitalist societies. Against the relativism and nothingness of the will that characterises the passive nihilist, the radical nihilist would rather will nothingness in the name of an absolute value. We are thus confronted by a picture of the social space characterised by an oscillation between value relativism and value absolutism, the will to nothingness and the nothingness of the will. Significantly for our own discussion, returning to the preliminary definition of a loser as the holder of a defeated system of values emerging from an authentic conflict. With the disjunctive synthesis of the loser and the radical loser, of value relativism and impossible values, there can be no winner as there is no authentic conflict. In this picture of the social space neither side can emerge victorious. To make the claim, that there are no winners, only losers and radical losers sounds paradoxical, how can one lose if no one can win? - although the conflict is a false one it is nonetheless a conflict, but a conflict that cannot resolve itself. From this perspective I would argue there can only emerge losers.

\section{Dual economy of spiteful rage and commodified sexual relations}

I will torture some of the good looking people before I kill them, assuming that the good looking ones had the best sex lives. All of that pleasure they had in life, I will punish by bringing them pain and suffering. I have lived a life of pain and suffering, and it was time to bring that pain to people who actually deserve it. (Rodger, 2014:132)

This quotation is taken from the mass murderer Elliot Rodger's manifesto "My twisted world", who on the evening of May 23rd, 2014 killed six people and injured fourteen others. After he stabs his flatmates and shoots three women outside a sorority house, he exchanges gun fire with police officers while speeding through Isla Vista California firing his weapons at pedestrians and hitting them with his car. The rampage came to an end when he crashed into a parked car and took his own life. There are clearly misogynistic, racist, elitist and narcissistic motivations for his attack detailed in his journal. Both his manifesto and his YouTube videos go into extensive details about his sexual frustration and his resentment towards women who would not sleep with him as well as men who were sexually active, "especially good-looking ones" (Rodger, 2014:132). In addition, Rodgers demands include those for justice, recognition and the forcing of the world to fit his own desires

I spent more time studying the world, seeing the world for the horrible, unfair place it is. I then had the revelation that just because I was condemned to suffer a life of loneliness and rejection, doesn't mean I am insignificant. I have an exceptionally high level of intelligence. I see the world differently than anyone else. Because of all of the injustices I went through and the worldview I developed because of them; I must be destined for greatness. I must be destined to change the world, to shape it into an image that suits me! (Rodger, 2014:56)

To understand these dimensions of Rodger's mass murder/suicide in their full totality and social context it is my contention they must be understood as a spiteful, rage economy produced within the framework of the capitalist social formation. This section of the article thus takes the affectual constellation of Rodger as a paradigmatic case for the exploration of the disjunctive synthesis of radical and passive nihilism as manifested in the capitalist social 
formation. According to Simmel (2012:35), the modus operandi of the capitalist economy is the frightful levelling of all things, the abolition of qualitative value for the quantitative common denominator that is money. Indeed, capitalist exchange takes place independently of the values of the seller and the buyer, reducing the relationship between things and people to what is "objectively perceivable" (Simmel, 2012:32). Put differently, capitalism sets into motion the process Marx described as commodity fetishism, in which the commodity's colonisation of social life for Debord (1994:13) was completed in the historical moment which corresponds to the spectacle. For Diken (2008:70) "the capitalist concept of value is nihilistic: capital as an abstract entity that, instead of relating itself to an exteriority, relates itself only to itself, or, 're-enters' itself.". Furthermore, it is the logic of surplus value which necessitates the separation of one's personal values from their engagement with people and things, making capitalism the age of the greatest cynicism (see Deleuze and Guatarri 1983:222). Capitalist cynicism makes it so those inferior, reactive forces concerned with selfpreservation triumph over the superior active forces that animate noble forms of evaluation (See Deleuze, 2006:58). Thus, with capitalism, weakness and wealth are not opposed but complementary flows. One can be "successful" and marked by a fundamental weakness. Hence anyone in this sociality can become a radical loser, mass murder/suicide cannot be explained on the basis of economic impoverishment.

Despite the cynicism of the monetary economy reducing all people values and things to what is objectively perceivable it brings with it a nihilistic form of enjoyment. An enjoyment of this very process, namely the enjoyment of the reduction of all things to something purchasable (Diken, 2008:69). The reduction and concentration of purchasable things stimulates the individual to the highest degree of nervous energy (Simmel, 2012:35). Further, the reduction of people and things to what is objectively perceivable is coupled with the augmentation of needs "The spectacle is a permanent opium war waged to make it impossible to distinguish goods from commodities, or true satisfaction from a survival that increases according to its own logic" (Debord, 1994:13). The logic of capitalist accumulation from this perspective increases what can be purchased, blurring the lines between the feeling of satisfaction or its artificial or simulated form. With neoliberalism and its anthropotechnical project of scripting all the excessive dimensions of humanity, their passions, desires, emotions to economic principles (see Rossi, 2018:1) results in their derisory preservation. We can observe this derisory preservation in the commodity as spectacle, which attempts to separate reality and the image (Debord, 1994:5-6). One way in which this separation manifests itself is through the de-coupling of commodities from their malignant substances (see Žižek, 2004). That is to say products such as alcohol-free beer or decaffeinated coffee signify a post-modern injunction for moderation, it is a modest pleasure of the passive nihilist. What is significant about these seemingly banal products is the removal of the bodily experience by the commodity understood as the direct embodiment of fetish value, whose relationship to the real is purely spectral (See Diken, 2008:69). In the case of Eliot Rodger, the experience of this separation between reality and the image in his own life can be encapsulated with reference to Houellebecq's novel "The possibility of an island"

...to increase desires to an unbearable level whilst making the fulfilment of them more and more inaccessible: this was the single principle upon which Western society was based. (Houellebecq 2005: 57)

Rodger documents his daily experience as one of miserable loneliness, rejection and insignificance in which his desire to enjoy sexual advantage is concurrent with is rage and ressentiment. "I found some posts on the internet about teenagers having sex, and I was once 
again reminded of the life I had been denied... I developed extreme feelings of envy, hatred, and anger towards anyone who has a sex life" (Rodger, 2014:56). What is significant in Rodger's description of his loneliness and the reasons for this is the lack of substance he attributes to the other, his enemies. When he talks about his enemies, they have no names they are simply "males" and "females' bare life, bodies without names who possess something he does not and who are therefore worthy victims of extreme cruelty. "I wanted to kill them slowly... They deserve it. The males deserve it for taking the females away from me, and the females deserve it for choosing those males instead of me." (2014:87). Such a logic is reminiscent of Simmel's description of the reduction of the relationship between people to what is objectively perceivable (2012:35). Rodger's rage at the other was not a result of a love rivalry in which he was the loser nor was it one of direct rejection from a woman whom he had strong feelings for. His anger was towards all women who would not give him what they possess in his view (sex) and all men who kept this resource for themselves. Rodger's perception and depiction of sexual relations is like that of the author Houellebecq who depicts sex as a naked spectacle with no seduction. "On the sexual level there were those who aroused desire, and those who did not" (Houellebecq, 2005:21).

This form of sexual differentiation in Houellebecq follows the logic of a marketized society in which sexual life is reduced to what is objectively perceivable, one's desirability which corresponds to one's sexual market value. Hence his emphasis on the values of "beauty, youth, wealth, ambition, and sex" (Houellebecq, 2005:21). Following the same logic, for Rodger sex functioned like that of capital and creates the perception that the neoliberal ideological distinction between winners and losers extends to sexual life. Indeed, much like "In a totally liberal economic system, certain people accumulate considerable fortunes: others stagnate in unemployment in misery. In a totally liberal sexual system, certain people have a varied and exciting erotic life: others are reduced to masturbation and solitude." (Houellebecq, 1998:99). In the fictional world of Houellebecq, this struggle against the sexually advantaged can culminate in the injunction for equal enjoyment "a demand for sexual 'justice' through which everybody can have free access to everybody's body" (Diken, 2008:98). However, in actuality as it is impossible to impose equal enjoyment, Rodger's spite attempted to impose an equal prohibition. Rodger responded to the perceived excess enjoyment of the other through the redistribution of his pain to those who are perceived as acutely lacking pain (See Sloterdijk, 2010:63). Hence Rodger's (2014:132) desire to punish those with "the best sex lives" repaying their pleasure in life with pain and death. Following a perspective that is perfectly in accordance with a society of Market led values, Rodger's pain and ressentiment was exaggerated to the point it was able to transcend a depressive paralysis (See Sloterdijk, 2010:55). Believing he was the loser of marketized rules of sexual life, Rodger's concomitant rage economy culminated in a spiteful equalisation, a suicidal will to win for a moment. What Rodger was responding to was the spectacle itself. Indeed, today the injunction is to enjoy, and guilt emerges from one's inability to enjoy rather than as a result of excessive enjoyment. What Rodger was unable to see is there can be no winners in a system of marketized sexual relations as it attempts to reduce the subjective experience to a quantifiable possession which individuals are continually pressured to display. That is the real kernel of the problem that links Rodger's subjective experience to the generalised experience of the spectacle, namely the gap between reality and the image. What Rodger did was mistake the image for reality, attacking the real when his actual target was the image. Thus the antagonism is not between sexual success and failure, but between seduction and the obscene, between the injunction to simulate enjoyment and the refusal to do so. 


\section{Spectacular mass murder or the ecstasy of violence.}

The logic that is characteristic of the spectacle, of the separation of reality and the image is coming to increasingly dominate all aspects of experience. Indeed, through pornography one can simulate sex that is devoid of sex, and its affectual relation to the body of the other: one can kill without killing either through video games or vicariously through the simulated adventure of the hero or villain in the cinema, video game or television. Crucially in this context following Berardi (2015:35) we must avoid a superficial conclusion that it is the content of violent video games or films that de-sensitise one to the bodily experience of pain and cruelty. it is Rather "the stimulation itself, that produces the effect of desensitization to the bodily experience of suffering and of pleasure" (Beradi, 2015:35). On the one hand one could argue this situation is reminiscent of Baudrillard's (1997:451) extreme phenomena: those which occur beyond the end of the real, the paradoxical end of an idea via its excessiveness "(extreme = exterminis)". However, Baudrillard himself knew that processes of hyper realisation or integralisation understood as the "perpetrating on the world of an unlimited operational project whereby everything becomes real, everything becomes visible and transparent, everything is 'liberated" is subject to reversal and a violent counter transference (see Baudrillard, 2005:17-185). Put differently, we can argue mass murder is the violent return of the real which the spectacle has sought to conceal or exorcise. That is to say, the deficit of the real and real bodily experience is paired with the ultra-real or excessive perpetration of violence upon the body, a radical nihilist's desire for extremity against the passive nihilist's injunction for moderation, the separation of the body or will from the objects of desire. This argument is perhaps best exemplified by the actions of the mass murderer James Eagan Holmes who thought of himself as the joker from the Batman comics. On the twentieth of July 2012 Holmes entered a century 16 movie theatre that was showing the latest batman film "Batman the Dark Knight Rises" and opened fire on the people inside killing 12 and injuring 70 others. What is significant about this mass shooting is its location, namely a cinema, the perfect embodiment of the society of the spectacle, the separation of the real and the image. Following Berardi(2015:33), Holms developed and subverted the relationship between crime and the media ...

While Harris and Klebold were hoping for Spielberg's attention, Holmes was already mimicking a character from Nolan's movie. Holmes is already part of the world of Batman, reconfiguring DC's creation in reality, dissolving the boundary of the screen and forcing the audience to participate in the story that they have chosen merely to watch. For the spectacular mass murderer, the aim is to break the mirror of the spectacle. For him, the border between reality and imagination are blurred, indistinct, distorted. He wants to take part in the spectacle, so that the spectacle may become life, and - ultimately - death.

It could be argued the actions of both Holmes and Rodger can be understood as the paradoxical ecstasy of simulated bodily experience, its violent counter transference in which the separation between the image and reality is forced together. The difference is that Holmes intentionally mimicked the spectacle attempting to make it a part of real life and real death. Rodger mistook the spectacle for the real, attacking the real when it was the naked spectacle of marketized sexual relations that was his real enemy.

\section{Conclusion}

To conclude, what the two losers of modernity fail to comprehend is their proximity to one another, the radical loser sees in the passive nihilist a winner of the social game without considering that there can be no winner in the social game, that the neoliberal ideological 
construction of winners and losers amounts in actuality to a disjunctive synthesis. A false and staged conflict in which there can be no winner only losers and radical losers. On the other hand, the passive nihilist never stops to think that they too are a loser. For the passive nihilist or loser of modernity people like Rodger are uncanny because contrary to the popular slogan for serial killer documentaries "entering the mind of a serial killer", we too are already half occupying the mentality that fuels systemic acts of spite. If we accept the logic of neoliberalism, then we are participating in the production of radical losers. Indeed, we can argue with Berardi (2015:4) that with neoliberalism the age of heroes comes to an end, supplanted by the commodified hero. The spectacle's colonisation of social life means one comes to see their very subjectivity, their very existence as a spectacle for the others consumption, a disposition that is encapsulated by Mae, the protagonist of Eggers dystopic novel "The Circle" "I want to be seen. I want proof I existed" (Eggers, 2013:484). What the radical loser does is take this desire to its logical extreme, ignored in life but recognised in death as an abject hero, the joker or the supreme gentleman, he does not subvert the spectacle but affirms its hyper negative terroristic dimension. As Baudrillard (2003:414) puts it "the spectacle of terrorism imposes the terrorism of the spectacle". What makes the mass murderer a new terrorist is their perverse affirmation of a negative sociality, a hyperreal violence produced by a hyperreal society. Thus, their violence could be characterised as a resentful and desperate performance, that although produces fear, shock and moral outrage expresses the internal affects and desires of a commodified, vacuous pseudo culture. The mirror image of a butchered sociality in which the will to participate in the spectacle results in real death and the spectacle of death.

What we are left with then is the question concerning how this deadlock between losers and radical losers, between radical and passive nihilists can be over-come? How might thymotic impulses be productively channelled towards the trans-valuation of value relativism and value absolutism which are informed by the concomitant affects of spite and passivity without returning to a transcendental reality principle. Indeed, whether there are examples of a kind of large-scale secular rage bank pacifying radical nihilism is an investigation beyond the scope of this article. However, the line of argumentation I have pursued suggests that if we are to plot a course towards a sociality that is not caught in this vicious cycle the answer does not lay in "Breaking" the mirror of the spectacle". Rather, it may consist of "Overcoming" the mirror of the spectacle.

\section{References}

Baudrillard J (1997) The End of the Millennium or the Countdown, Economy and Society, 26(4): 447-455.

Baudrillard J (2003) The Spirit of Terrorism. London: Verso.

Baudrillard J (2005) The Intelligence of Evil or the Lucidity Pact. New York, NY: Berg.

Berardi F (2015) Heroes: Mass Murder and Suicide. London: Verso.

Dostoevsky F (1992) Notes from Underground. New York, NY: Dover Publications.

Diken B, and Laustsen C B (2004) 7-11, 9/11, and Postpolitics. Alternatives: Global, Local, Political 29(1): 89-113. 
Diken B (2008) Nihilism. London: Routledge.

Diken B (2009) The (Impossible) Society of Spite: Revisiting Nihilism. Theory, Culture \& Society 26(4): 97-116.

Debord G (1994). The Society of the Spectacle. New York, NY: Zone Books.

Deleuze G (2006) Nietzsche and Philosophy. London: Continuum.

Deleuze G, and Guattari F (1983) Anti-oedipus: Capitalism and Schizophrenia. Minneapolis, MN: University of Minnesota Press.

Enzensberger HM (2005) The Radical Loser. Available at:

http://www.signandsight.com/features/493.html (accessed 9 August 9, 2019).

Eggers D (2013) The Circle. McSweeny's Books: San Francisco, CA.

Guattari F (2008) Everybody wants to be a Fascist. In: Lotringer, Sylvère (ed.) Chaosophy, Texts and Interviews 1972-1977. Massachusetts, MA: The MIT Press, pp. 87-98.

Houellebecq M (1998) Whatever. Paul Hammond: London.

Houellebecq M (2005) The Possibility of an Island. London: Weidenfeld \& Nicolson.

Laclau E (2005) On Populist Reason. New York, NY: Verso.

Nietzsche F (1960) Joyful Wisdom. New York, NY: Frederick Ungar Publisher.

Nietzsche F (1967) The Will to Power. New York, NY: Vintage.

Nietzsche F (1996) On the Genealogy of Morals. London: Oxford University Press: London.

Nietzsche F (2016) Thus Spoke Zarathustra. Jester House Publishing.

Rodger E (2014). My Twisted World. Available at:

https://www.documentcloud.org/documents/1173808-elliot-rodger-manifesto.html (Accessed 22 April 2018).

Rossi A (2018) Neoliberal Ruhlar / Neoliberal Souls. Cogito 91: 121-153.

Regan H, and Sidhu S (2019) Brenton Tarrant: From gym trainer to murder suspect. Available at: https://edition.cnn.com/2019/03/16/asia/new-zealand-suspect-brenton-tarrantabout-intl/index.html (accessed 23 April 2019).

Scheler M (1994) Ressentiment. Wisconsin, WI: Marquette University Press.

Simmel G (2012) The Metropolis and Mental Life. in Lin J and Mele C (eds) The Urban Sociology Reader. Abingdon, Oxon: Routledge, pp.30-45. 
Sloterdijk P (2010) Rage and Time: A Psychopolitical Investigation. New York, NY: Columbia University Press.

Wigham N (2019) Christchurch shooter's hidden messages buried in manifesto. Available at: https://www.news.com.au/technology/online/social/christchurch-shooters-hidden-messagesburied-in-manifesto/news-story/b9c4b070abda5a42368e2247e19d8efd (accessed 23 April 2019).

Žižek S (2004) Passion in the Era of Decaffeinated Belief. Available at: http://www.lacan.com/passionf.htm (accessed 11 August 2019).

For correspondence: Oliver Simpson, Department of Sociology. Lancaster University, Lancaster United Kingdom LA1 4YW Email: o.simpson2@lancaster.ac.uk 